\title{
VALUE CREATION IN THE LISTED BANKS: DO GOVERNANCE MATTER?
}

\author{
Abdul Mongid* \\ STIE Perbanas Surabaya \\ R. R Iramani \\ STIE Perbanas Surabaya \\ Muazaroh Muazaroh \\ STIE Perbanas Surabaya
}

\begin{abstract}
We assess the relationship between bank governance practice (GCG), efficiency, capital and risk on value creation in a sample of Indonesia commercial banks using the balance panel methodology. Our results suggest that GCG has a positive impact on value creation and performance. We also find that higher interest margin eventually becomes more profitable, better capitalized and that higher capital levels tend to have a neutral or negative effect on value creation. Efficiency levels are positive to value creation. These results are generally confirmed by a series of robustness tests. The findings convey potentially important implications for bank prudential supervision and underline the importance of attaining better governance to support sustainability and financial stability objectives.
\end{abstract}

Keyword: Governance; Economic value added; Public bank; Efficiency; Performance.

Received: 21 May 2019

Accepted: 20 May 2020

\section{INTRODUCTION}

There is continuing interest to improve the performance ofthe banking industry as necessary condition to forge a stable and healthy banking system. There has been much discussion over the extent to which governancehas contributed to the performance of the banks, particularly in the aftermath of the global financial crisis (GFC) in 2008. There is considerable recent literature on bank performance including Berger and Mester (2003), Athanasoglou et al. (2006), Athanasoglou et al. (2008), Laeven and Levine (2009), Goddard, Liu, Molyneux and Wilson (2011), Mongid and Muazaroh (2017) and Ghalib (2018). These studies focused on bank profits using accounting profitability, such as ROA (Return on Asset) and ROE (Return on Equity). The contribution of governance tobank performance is however quite mixed. Some positive contributions have been recorded such as Iramani, et al (2018), Haryati and Kristijadi (2014) and Hanifa and Hudaib (2006). In contrast, De Han and Vlahu (2016), Bauer, Guenster \& Otten (2004), Le \& Buck (2011), Aebi, Sabato and Schmid (2012) recorded negative impacts.

\footnotetext{
* Corresponding Author: Abdul Mongid, Postgraduate Department of STIE Perbanas Surabaya, 36 Nginden Semolo, Surabaya, Indonesia,Email: mongide@perbanas.ac.id, Tel: +62315947151
} 
In this paper the approach adopted forbanking performance in Indonesia differs from those of earlier studies in two perspectives. The first is in the measurementof performance. In most previous studies theROA and ROEwere used as performance measures. In this study, we applied instead the Economic Value added (EVA) measure. Secondly, we adopt the panel data method which is relatively superiorto previous methods such as the Ordinary Least Square (OLS). Additionally, the study differs in its application of the implied risk free rate. Most studies on EVA adopted therisk free rate taken from the government's debt instrument. In the Indonesian context this same measure may differ greatly between that of the central bank, ministry of finance and the deposit insurance company. Alternatively, the implied risk free rate from the market provides a more consistent measure since various aspects are taken into consideration. Another novelty in this study is the effort taken to link bank productive efficiency (CIR) to EVA as a measure of shareholder value creation. Suhartono (2017) earlier concluded that productive efficiency was determined by capital, size and asset composition of the banks. In this study these variables are elucidated further on whether they provide a positive link between improvements in productive efficiency, capital and asset composition, and the EVA.According to Radic (2015), Fiordelisi and Molyneux (2010) and Fiordelisi (2007), Munteanu and Brezeanu (2012), Chong, Rusnah and Ghani (2016), Saha, Ahmad and Yeok (2016), EVA is a better measure to assess bank profitability since itconsidersinvested capital andlevel of risktaken. The traditional profitability measurements, such as ROA or ROA, may result in ambiguous interpretations such as on bank soundness or excessive risk taking.Further, Berger and DeYoung (1997)mentioned that high efficiency and profitability were due to skimping practices which reduce cost at the expense of loan quality in the future.

The objective of this paper is to augment the literature oneconomic value added forbanks together with its determinants. The paper will also examine the role of the contribution by governance increating value added for banks. It should also serve asan evaluation yardstick for the implementation of Good Corporate Governance (GCG) rule in Indonesia as required under the Bank Indonesia Regulation (PBI) No. 8/4/PBl/2006, issued on 30th of January 2006. This regulation is continuously being adapted to adjust to changing conditions. The aim of this studyis to examine factors that affect financial performance of public banks in Indonesia. In particular whethergovernance rating (GCG), capital position, credit risk, efficiency and bank size are influential in value creation in banking.

\section{LITERATURE REVIEW}

There are three fundamental theories that support the needforcorporate governance. Theseare the Agency Theory (Fama and Jensen, 1983, Jensen and Meckling (1976), the Stewardship Theory (Davis, Schoorman and Donaldson (1997) and Stakeholder Theory (Donaldson \& Preston (1995). However, these theories are less useful in explaining bank governance in Indonesia. The governance system in the country is more for creating soundness from the banking authority perspective and to a lesser extent for the benefit of the shareholder. Darmadi (2013) examined the practice of GCG in Indonesia and discoveredthat board member disclosure and risk management frameworks were very strong since both are tightly regulated. Conversely though, internal controls, remuneration committees and minimum committees are very weakly controlled.

Empirical results showed that the role of governance on bank performance were rather mixed. Extant evidences mostly support the contribution of GCG on performance.Recently, Utama and Utama (2014), Utama, Utama and Amarullah (2017) and Iramani, Muazaroh and Mongid 
(2018) investigated the contribution of governance towards bank performance and the value of the firm. Utama, Utama and Amin (2016) concluded that GCG reduces the cost of borrowing and improves corporate ratings. Haryati and Krisitjadi (2014) posited that governance was important for performance. They defined performance as financial ratios such as NIM, ROA, and ROE. Putra and Simanungkalit (2014) found GCG to be the key to increasing company value and the cost of debt. Haniffa and Hudaib (2006) showedthat GCG improved the ROA and market Tobin-Q.

The correct application of GCG is difficult in practice. Wijaya and Atmoko (2015) found that it was very difficult to fully implement GCG because of constraints in the political system and bad governance. Conversely, Sutopo, Trinugroho and Damayanti (2017) found that political relations weregood for bank performance. Mongid and Tahir (2011) discovered that corruption was positive for bank performance in the ASEAN. In a recent case involving Islamic banks, Arshad and Rizvi (2013) concluded that these banks were thriving on corruption. On the contrary, the study by Murharsito, Fauziah, Kristijadi and Iramani (2017), using bank samples from Indonesia, concluded that corruption was detrimental to development of bank profitability since it was constrained by local political condition.

The impact of governance on performance had been thoroughly investigated. Li and Weidong (2003) found that governance improved the performance of Chinese banking following privatization of the sector. Nur'ainy, Nurcahyo, Kurniasih and Sugiharti (2013), using Indonesian samples, revealedthat the application of GCG had positive contribution to EVA. Findings by Okike and Turton (2009) supported the positive contribution of GCG to bank performance in the UK. In contrast. De Haan and Vlahu (2016), in a literature survey, showed that GCG had positive impact on non-banks but not so on the banks.

Further to the study by Steward (1992), on the superiority of Economic Value Added (EVA), Yun, Yiping, Jin (2004) demonstrated through EVA calculationshow Chinese banking createdvalue. Xin'e, Ting, \& Yuan (2012) suggested that innovation can increase the value creation capabilities for commercial banks in China. Hornuf, Klus, Lohwasser\& Schwienbacher (2018)examined the positive relationship between Fintech creation and EVA using bank samples from Canada, France, Germany, and the United Kingdom.Teker and Sönmez (2011), using samples from Turkey, suggested that EVA was a better measure for bankperformance relative totraditional indicators such as ROA and ROE. Using multiple pool regression models, Haddad (2012) examined the relationship between EVA, ROA, ROE and capital adequacy ratio (CAR) on stock returns in Indonesia. They concluded that there was a positive and significant relationship between EVA and banking stock returns.

In the ASEAN situation, Dewanti and Rokhim (2017) investigated the comparative performance of bank firms in Indonesia, Malaysia, Singapore, Thailand and the Philippines as listed on the Stock Exchange of each country using the performance of EVA. They found EVA a better financial indicator than traditional financial ratios. Saha, Ahmad and Yeok (2016), using Malaysian bank samples, showed that bank performance using EVA in Malaysia improved overtime. Munteanu and Brezeanu (2012) documented similar results when EVA was applied on the banking institutions in Romania. Mandilas, Floropoulus, Pipiliagkopoulus and Angelakis (2009) studied the contribution of EVA to stock returns on the Athens,Stock Exchange in Greece. They found that Earning Per Share (EPS) was significantly determined by ROA, and ROE and EVA. However, EVA was shown to be the most consistent while EPS registeredthe highest 
contribution. When EVA wascombined with EPS, the explanatory power of stock returns increased relative to each variable itself.

EVA is also an important indicator for Islamic institutions. Chong, Rusnah and Ghani (2016) studied EVA for Islamic banksin Malaysia from the perspective of investment. They developed a modified EVA model that was used forinvestors' (shareholders and providers of revenue sharing) value added measurement. The adoption of the EVA model increased value added for theIslamic banks. The finding suggested that for their operations it was necessary for Islamic banks to apply value added models for providers of equity and equity capital. Mollah, Hassan, Al Farooque, and Mobarek (2017), using bank samples from several Islamic countries, arrived to similar conclusions that governance reduced risk and improves efficiency. In relation to competition Zheng (2014) suggested that EVA wasa good indicator of bank performance in China which provided a good road map to enhance efficiency, sustainability and competency. The study also implied thatEVA can fully reflect bank's operating conditions as well as better management and risk control capabilities.

GCG is however not immune to influence of hostile environment. In a study on European and US banks Beltratti and Stulz (2009) found it ironic that banks with a more shareholder-friendly board performed the worst during the banking crisis. Conversely, banks operating in countries with tighter capital requirements and stronger and independent banking supervision performed relatively better. This suggested that GCG and bank supervision were not the suitable substitutes.Peni and Vähämaa (2012) produced mixed results in that while governance improved profitability, it also simultaneously lowered stock market price during the crisis. Additionally, Aebi, Sabato and Schmid (2012) suggested that traditional GCG performs poorly during crisis. Yeh (2017), in a study on Japanese regional banks, supported their finding. Williams (2014) postulated that state governance reduced risk taking in Asian banks.

\section{DATA AND METHODOLOGY}

In this paper, we used 180 bank samples from 20 banks for the period 2009 to 2017 . We only used samples that have complete data since we applied only fully balanced panel data. The samples covered only $47 \%$ of the total public banks (43 banks). However, in terms of asset, they contributed more than $75 \%$ of total bank assets.

The definition of GCG, according to the Central Bank Regulation (PBI) number 8/4 / PBI / 2006, is bank governance that applies the principles of transparency, accountability, responsibility, independence, and fairness. The Indonesian Financial Service Authority (OJK) applies a GCG rating based on eleven GCG indicators. These include the implementation of tasks and responsibilities of directors, implementation committee assignments, handling conflicts of interest, implementation of compliance, implementation of internal and external audit functions, the risk management and control system, funding provision to related parties, transparency of financial and non-financial conditions and bank's strategic plan.

EVA (Economic Value Added)is a measure of the company's profit after deducting all the costs of the invested capital. EVA is calculated as net income minus or reduced by costs for capital usage. This can be written with the following formula: 
EVA $=($ Net operating profit after tax $($ NOPAT $)-$ Capital $*$ Capital Cost $)$

$\mathrm{EVA}=$ NOPAT $-($ Capital $*$ Capital Cost $)$

$\mathrm{EVA}=$ NOPAT - Capital Cost Expense

$\mathrm{EVATA}=\mathrm{EVA} /$ Total Asset

where NOPAT represents "net operating profit, after tax", and "capital cost" is the amount of capital multiplied by the cost of capital. Cost of capital is measured using the implied risk free rate. EVA differs from the conventional profit or income model such as NOPAT that reflects operating income. EVA assumes that management must produce sufficient income not only to cover operating costs and interest expense on debt, but also toprovide a minimum return required by the shareholders as compensationoninvestment. EVATA is EVA divided by total asset. Figure 1 presents the framework of the study. The definition of the variables is also shownin Table 1 .

Table 1: Variables, Defintion and Sources

\begin{tabular}{|c|c|c|c|c|}
\hline No & Variable & Definition & Data & Expected \\
\hline & & Dependent Variable & & \\
\hline 1 & EVATA & (Profit - Cost of Capital) / Total Asset & BS/IS/IMRP & \\
\hline 2 & ROA & Profit / Total Asset & BS/IS & \\
\hline 3 & ROE & Profit After tax / Total Asset & $\mathrm{BS} / \mathrm{IS}$ & \\
\hline & & Independent variable & & \\
\hline 1 & GCG & Inverse GCG rating & GCG Report & Positive \\
\hline 2 & NPL & Problem Loan / Total Loan & $\begin{array}{l}\text { BS/Quality } \\
\text { report }\end{array}$ & Negative \\
\hline 3 & NIM & $\begin{array}{l}\text { (Interest Income - Interest Expenses)/Productive } \\
\text { Asset }\end{array}$ & $\mathrm{BS} / \mathrm{IS}$ & Positive \\
\hline 4 & LASSET & Log Total Asset & BS & Both \\
\hline 5 & ETA & Equity Capital / Total asset & $\mathrm{BS} / \mathrm{IS}$ & Positive \\
\hline 6 & CIR & Total operating expenses/ Total operating Revenue & IS & Negative \\
\hline 7 & LTA & Loan / Total Assets & BS & Positive \\
\hline 8 & CAR & Eligible Capital/ Risk Weighted Asset & BS & Positive \\
\hline
\end{tabular}

$\mathrm{BS}=$ Balance sheet, $\mathrm{IS}=$ Income Statement, IMRP $=$ Implied Market Risk Premia

Table 1 presents the variable, definition and the sources of data. To calculate the EVA, we used the from-market risk premium that provides IMRP (Implied Market Risk Premia) for Indonesia. Sincethe data wasmonthly; we averaged it out to get the annual risk free rate. The data were sourced from the website www.market -risk-premia.com. The mean for IMRP was $8.33 \%$ with the standard deviation $1.88 \%$. The minimum was $5.82 \%$ and maximum rate $12.24 \%$. We deductedtotal capital with fixed asset to give a more comprehensive view of real capital investment for business. We also estimated the profitability using traditional measures such as ROA and ROE for comparison.

For GCG, we obtainedthe data from the GCG report for individual banks. We then inversed it to give positive figures. The original GCG rating value ranged from 1 to 5 , where 5 is the worst and 1 is the best. To give positive relationship, we inversed it using the 6-GCG rating. NPL refers to credit risk with the higher value indicating higher risk. NIM refers to the ability to generatemargin 
from lending business. A higher ratio is better sinceit can create higher profitability value. Size wasmeasured using the logarithm of total asset. Higher values may be better from an economic perspective as the result of economies of scale and scope. However, it can be negative to value creation if diseconomies of scale exist.

Figure 1:Research Framework

\begin{tabular}{|c|c|c|c|c|c|}
\hline $\begin{array}{c}11 \\
\text { Aspects }\end{array}$ & $\begin{array}{l}\text { GCG } \\
\text { Rating }\end{array}$ & $\Longrightarrow$ & $\begin{array}{c}\text { Inverse }= \\
\text { 6-GCG Rating }\end{array}$ & & \\
\hline \multicolumn{2}{|c|}{ NPL Problem loan / Total Loan } & & & & \\
\hline \multicolumn{2}{|c|}{$\begin{array}{c}\text { NIM = Net Interest Income / } \\
\text { Productive asset }\end{array}$} & & & & \\
\hline \multicolumn{2}{|c|}{ Size $=$ Logarithm of total asset } & & & & \\
\hline \multicolumn{2}{|c|}{ ETA $=$ Total equity $/$ Total Asset } & & \multirow{3}{*}{$\begin{array}{c}\text { EVATA } \\
\text { ROA } \\
\text { ROE }\end{array}$} & EVATA & $\begin{array}{l}\text { (NOPAT - Cost of } \\
\text { Capital)/Total Asset }\end{array}$ \\
\hline \multirow{2}{*}{\multicolumn{2}{|c|}{$\begin{array}{c}\text { NETCAPA= Equity- Fixed asset } \\
\text { and Inventarist/ Total asset }\end{array}$}} & & & ROA & Profit/Total Asset \\
\hline & & & & ROE & Profit/Total Equity \\
\hline \multicolumn{2}{|c|}{$\begin{array}{c}\mathrm{CIR}=\text { Total Expenses } / \text { Total } \\
\text { Income }\end{array}$} & & & & \\
\hline \multicolumn{2}{|c|}{$\begin{array}{c}\text { CAR = Eligible capital } / \text { Total } \\
\text { Risky Asset Total Expenses }\end{array}$} & & & & \\
\hline
\end{tabular}

For Capital, we applied ETA and CAR. ETA is equity to total asset and it represents how strong the capital is compared to the asset. CAR represents the ratio between equity to risk weighted asset. CAR can be misleadingas it doesn't depend on the equity invested, but more on how banks handle the risk. Efficiency is measured using CIR (Cost to Income ratio). A high ratio indicates a worse situation sinceCIR represents inefficiency measure. LTA represents asset diversification. A higher ratio indicateslow diversification. It also represents an ex-ante risk as higher ratio can also generate higher income. As lending is the main business of the bank in Indonesia, a higher ratio is favorable than a lower one.

Table 2: Data Description of Selected Variables (\%)

\begin{tabular}{ccccccc}
\hline \hline No & Variable & Obs & Mean & Std. Dev. & Min & Max \\
\hline $\begin{array}{c}\text { Dependent } \\
\text { Variables }\end{array}$ & & & & & & \\
1 & EVATA & 180 & 0.698 & 1.734 & -6.487 & 4.438 \\
2 & ROA & 180 & 1.023 & 1.227 & -0.690 & 4.450 \\
3 & ROE & 180 & 0.205 & 1.479 & -4.740 & 19.200 \\
\hline
\end{tabular}




\begin{tabular}{ccccccc}
\hline \hline No & Variable & Obs & Mean & Std. Dev. & Min & Max \\
\hline $\begin{array}{c}\text { Independent } \\
\text { Variables }\end{array}$ & & & & & \\
1 & GCG & 180 & 4.229 & 0.486 & 2.330 & 5.000 \\
2 & NPL & 180 & 1.924 & 1.715 & 0.000 & 11.000 \\
3 & NIM & 180 & 6.320 & 4.663 & 0.000 & 19.000 \\
4 & LASSET & 180 & 18.206 & 1.498 & 14.123 & 20.797 \\
5 & ETA & 180 & 12.598 & 7.694 & 3.307 & 25.736 \\
6 & CIR & 180 & 82.349 & 19.358 & 31.070 & 235.200 \\
7 & FATA & 180 & 2.618 & 1.397 & 0.357 & 9.772 \\
8 & CAR & 180 & 15.784 & 6.561 & 3.030 & 46.490 \\
\hline \hline
\end{tabular}

Note: all in percentage except GCG and LASSET

Table 2 presents the statistics of the variables in this study. There are 180 observations for ten year periods. The study utilized data from 2008-2017. There are three independent variables; EVATA, ROA and ROE. The mean for EVATA is 0.698 with the minimum -6.487 and maximum 4.438. For the ROA, the mean value is 1.023 with the minimum -0.690 and maximum value 4.450 . For the ROE, the mean is 0.205 with the minimum -4.470 and maximum 19.200. The biggest range is in ROE.

There are eight independent variables. The mean for GCG is 4.229 with minimum score 2.330. NPL on average was below the maximum level as required by the banking authority who indicated the maximum at 5\%. Beyond that level, the bank will be placed under the special care unit (Bank Special Care Unit). NIM represents the ability to generate income from the differencein interest. On average the NIM is $6.320 \%$ and the minimum is $0 \%$ and maximum $19 \%$. Lower NIM indicates a substantial managerial problem with the bank. Size (LASSET) represents the market power. The big bank enjoys economies of scale. On average the size is 18.206 withminimum 14.123 and maximum 20.797. The total asset of the biggest bank can be hundreds of time greater than that of the smallest bank.

There are two measures of capital. For the ETA, the mean value is 12.598 with minimum 3.307 and maximum 25.736. For the CAR, the mean is 15.784 and the minimum is 3.030. The bank with CAR value ess than $8 \%$ is automatically classified as unsound and will be placed underthe Special Care Unit (BDP). For efficiency (CIR), the average is 82.349 withthe best at 31.070 and the worst at 235.200. For the fixed asset ratio (FATA), the mean is 2.618 with minimum value of 0.357 and maximum 9.772 .

The general framework of research in this study will focus on gauging the influence of governance practices as measured by GCG rating on the performance of banks (EVA). In the measurement of risk, we used NPL as a credit risk measure (expost-risk) and Loan to total asset (LTA) as ex anterisk. For the performance, we also employedROA and ROE. The model can be simply presented as follows:

$$
\begin{aligned}
\mathrm{EVA}_{\mathrm{it}}= & \alpha_{\mathrm{it}}+\beta_{1} \mathrm{GCG}_{\mathrm{it}}+\beta_{2} \mathrm{NPL}_{\mathrm{it}}+\beta_{3} \mathrm{NIMit}+\beta_{4} \text { LASSET it }+\beta_{5} \mathrm{ETA}_{\mathrm{it}}+\beta_{6} \mathrm{CIR}_{\mathrm{it}}+\beta_{7} \text { FATA }_{i t} \\
& +\beta_{8} \mathrm{CAR}_{\mathrm{it}}+\varepsilon_{\mathrm{it}}
\end{aligned}
$$




$$
\begin{aligned}
& \mathrm{ROA}_{\mathrm{it}}=\alpha_{\mathrm{it}}+\beta_{1} \mathrm{GCG}_{\mathrm{it}}+\beta_{2} \mathrm{NPL}_{\mathrm{it}}+\beta_{3} \mathrm{NIMit}+\beta_{4} \text { LASSET }_{\text {it }}+\beta_{5} \text { ETAit }+\beta_{6} \text { CIR }_{\text {it }}+\beta_{7} \text { FATAit }_{\text {it }} \\
& +\beta_{8} \text { CARit }+\varepsilon_{\text {it }} \\
& \mathrm{ROE}_{\mathrm{it}}=\alpha_{\mathrm{it}}+\beta_{1} \mathrm{GCG}_{\mathrm{it}}+\beta_{2} \mathrm{NPL}_{\mathrm{it}}+\beta_{3} \mathrm{NIMit}+\beta_{4} \text { LASSET }_{\mathrm{it}}+\beta_{5} \text { ETAit }+\beta_{6} \text { CIR }_{\text {it }}+\beta_{7} \text { FATA }_{\text {it }} \\
& +\beta_{8} \mathrm{CARit}+\varepsilon_{\mathrm{it}}
\end{aligned}
$$

\section{RESULT AND DISCUSSION}

We apply the regression panel data analysis technique. Although this model is more suitable for the random effect, we follow procedures to identify the most appropriate model. The tools for such testing are the Bruche-Pagan (BP) test, Chow-test and the Hausman test. As the model fails the Bruche-Pagan (BP)-test and Chow-test, we would then utilizepanel data model. We use the Hausman test to select the fixed effects and random effects for the model.

Referring to the correlation among variables, we can see that all the predictors passed the correlation test as none exceeded 50\%. The highest correlation is between GCG and EVATA which accountedfor 27\%. Among dependent variables, only Lasset and GCG accountedfor 44\% correlation. The correlation between CIR and Asset size (LASSET) was-50\% indicating the existence of economies of scale. When we look at the Varian Inflation factors (VIF) none of the variable scored more than 2 , meaning that the multicollinearity is less apparent.

We find that for the EVA equation, the Adjusted-R-Squared value is between 0.230 and 0.320 and the simple OLS is applicable since the BP-test is 0.331 and not significant. Chow test end the same result. For the ROA equation, the Adjusted-R-Squared is 0.522 . We prefer to use the fixed effect model since the Hausman test results is 85 and significant at $1 \%$. For the ROE Equation, the Adjusted R-squared is 0.311 and thus the random effect model is applicable.

The LASSET is negative and significant at 1\%. This suggests that thelarger bankshavelower EVA. Theoretically, the value should be positive as bigger bankscan diversify theirincome sources and benefit from theeconomies of scale in theiroperations. There are two possible reasons for the result. The first is excessive capital that results inhighercost of capital which thusreduces extra income. The second is the lack of productive efficiency of large banks. It is clear from the negative correlation between Size and ROAthat profitability of largebanks is less than that of the smaller ones. We observed that the size and NIM arealso negative, indicating the lack of margin among the largebanks.

GCG is positive and significant for EVA. The result indicates that better governance positively createsvalue forthe banking firm. All models used produced positive coefficients thus confirming the consistent favourable effect of governance on performance. Governance was also significant for most of EVA and ROA models. Without considering the ROE models, GCG increasedvalue for the shareholders. This result is in line with those of previous studies such as Utama, Utama and Amarullah (2017), Iramani, et al (2018), Haryati and Kristijadi (2014), Putra and Simanungkalit ((2015), Okike and Turton (2009) and Dewanti and Rokhim (2017). The result also supported findings from international studies that suggest GCG as the best approach to improve bank performance (Yu, Yin and Jin, 2004; Xin'e, Ting and Yuan, 2012; Teker and Sonmez, 2011; Hornuf, et al, 2018). 


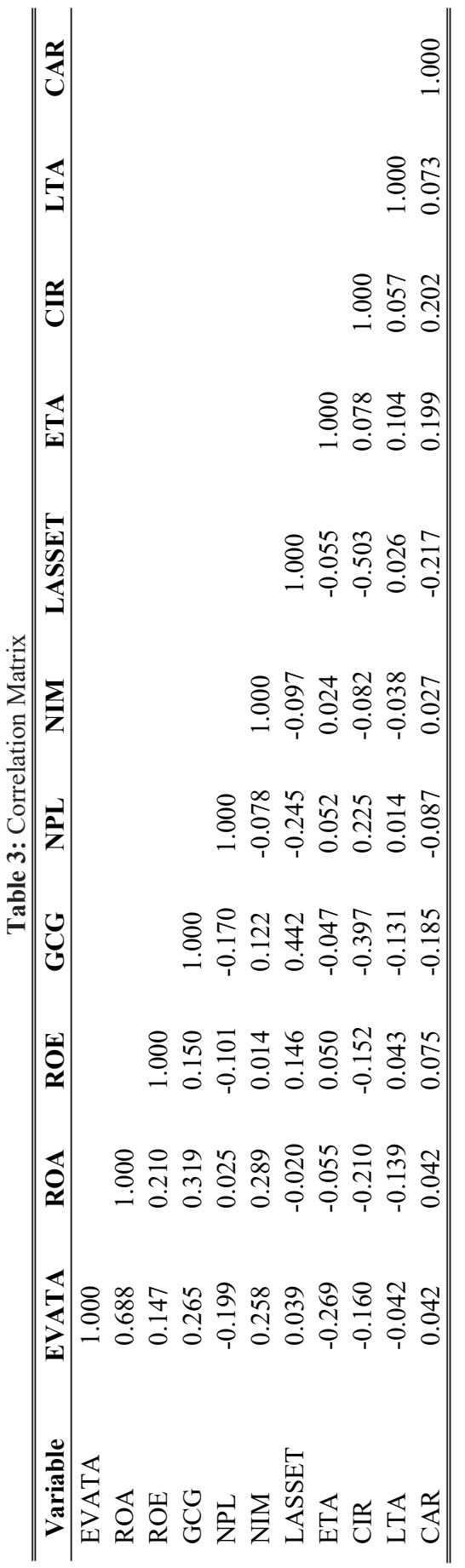




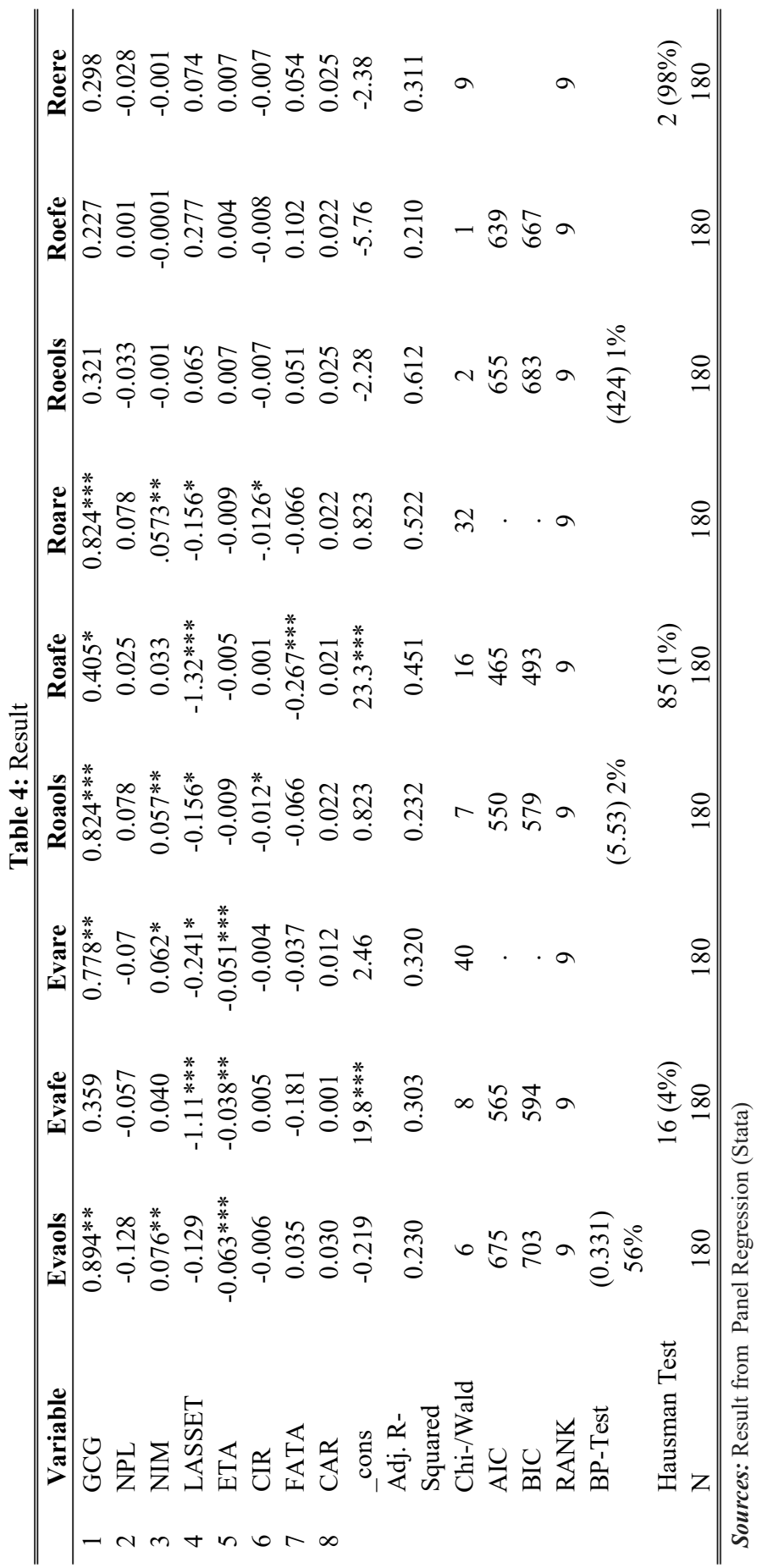


NPL is mostly negative and none is significant, indicating that credit risk exerts consistent negative impact onperformance. NPL is hazardous to profitability since it can reduce interest income and thus obliging the bank to fulfill loan loss provision to cover the risk. This finding was consistent with that by Akhigbe, McNulty\& Stevenson. (2017). in the relationship betweenNPL and governance, the result was partially consistent with finding by Tarchouna, Jarraya and Bouri (2017), especially in relation to small banks in the US. Small banks show better governance and have lower NPL. Mongid, Tahir \& Haron (2012) also found negative relationship between NPL andperformance but the result was not significant.

We conducted robustness test to confirm the result by regressing the dependent variables with GCG. The result waspositive and significant for EVATA and ROA thus confirming that GCG contributes positively to the performance of the bank. Most importantly, the impact of GCG and other bank specific variables on ROE bears no direct relationship(Table 4). None of the variables provided significant result implying that ROE is not determined by GCG and bankspecific variables. Furthermore, it is not possible to identify which variables correlate with ROE.

We can conclude that "GCG, NIM and ETA"can accurately predict the shareholder value creation for the sample banks. The finding may create an inconsistent implication sincecost efficiency, credit risk and bank size werenot significant. GCG is shown as the most important factor in explaining value creation in Indonesia. While interest margin is positive and significant, capital (ETA) is negative implying that there might be an excessive capital position. Interestingly, our results indicate that the smaller banks appear to have a higher value creation capability as designated by the negativesign. However, we have to be careful of possible excess capital in the sample bank as implied in the capital rule under the Basel II regime. We noticed a bank with the CAR greater than $45 \%$ (which is less than the optimal value) as the minimum capital adequacy ratio is only $8 \%$.

\section{CONCLUSION AND IMPLICATION}

Good corporate governance (GCG) is viewed as the foundation for better performance in the business firms. For the banking industry, the necessity for good governance is clear in all aspects of business operation. Our study shows that GCG are positive in influencing bank performance as measured using ROA and EVA. This should suggest that establishing comprehensive implementation of the GCG in national banking may assist the industry to grow rapidly and provide real contribution to national economic development. GCG was shown as significant in all models thus enhancing the importance of the management side to bank profitability performance. This finding is in line with international perspectives and regulations. The Basel Committee on Banking Supervision (BCBS: 2015) also emphasized the importance of effective corporate governance in the functioning of the banking sector and the overall economy. This finding is in accordance with that of previous research on the positive role of GCG in bank performance (de Haan and Vlahu, 2016). Size is also important to performance since the study showed that big banks are more profitable. However, capital strength was found negative and significant thus indicating the low capability of the industry to employ its capital to augment performance.

Since GCG is basically a system (input, process, and output) and a set of rules governing relationships between various stakeholders, assessment of the process is much more important than 
assesment of the structure. Therefore, the endeavor to improve governance in all aspects of the business in Indonesian banking should be conducted continuously. This study contributes to empirical studies in presenting strong evidence on the importance of implementing GCG in the banking sector. With reference to William (2014), firm level governance is important but improving governance at the national level is a prerequisite and crucial condition in creating a stable and reliable banking system.

\section{ACKNOWLEDGEMENT}

The authors express their appreciation for the funding support from the Ministry of Research, Technology and Higher Education, Indonesia, Contract Number SP DIPA-042.06.1.401.516/2018 Dated 5th of December 2017

\section{REFERENCES}

Aebi, V., Sabato, G., \& Schmid, M. (2012). Risk management, corporate governance, and bank performance in the financial crisis.Journal of Banking and Finance, 36(12), 3213-3226. doi:10.1016/j.jbankfin.2011.10.020

Akhigbe, A., McNulty, J. E., \& Stevenson, B. A. (2017). Additional evidence on transparency and bank financial performance. Review of Financial Economics, 32, 1-6.

Arshad, S., \& Rizvi, S. A. R. (2013). The impact of global financial shocks to Islamic indices: Speculative influence or fundamental changes? Journal of Islamic Finance, 176(814), 1-11.

Athanasoglou, B. P., Delis, M. D., \& Staikouras, C. K. (2006). Determinants of bank profitability in the South and Eastern European region, Bank of Greece Working Paper No. 47, September.

Athanasoglou, P. P., Brissimis, S. N., \& Delis, M. D. (2008). Bank-specific, industry-specific and macroeconomic determinants of bank profitability. Journal of International Financial Markets, Institutions and Money, 18(2), 121-136.

Bauer, R., Guenster, N., \& Otten, R. (2004). Empirical evidence on corporate governance in Europe: The effect on stock returns, firm value and performance. Journal of Asset Management, 5(2), 91-104.

Beltratti, A., \& Stulz, R. M. (2009). Why did some banks perform better during the credit crisis? A cross-country study of the impact of governance and regulation (No. w15180). National Bureau of Economic Research.

Berger, A \& R. DeYoung (1997). Problem loans and cost efficiency in commercial banks. Journal of Banking \& Finance, 21(6),

Berger, A. N., \& Mester, L. J. (2003). Explaining the dramatic changes in performance of US banks: Technological change, deregulation, and dynamic changes in competition. Journal of Financial Intermediation, 12(1), 57-95.

Chong, H. L., Rusnah, M., \& Ghani, M. A. (2016).Economic value added model for the Islamic bank investors. IJABER, 14(2), 915-938.

Darmadi, S. (2013). Corporate governance disclosure in the annual report: An exploratory study on Indonesian Islamic banks. Humanomics, 29(1), 4-23.

Davis, J. H., Schoorman, F. D., \& Donaldson, L. (1997). Toward a stewardship theory of management. Academy of Management review, 22(1), 20-47. 
De Haan, J., \& Vlahu, R. (2016). Corporate governance of banks: A survey. Journal of Economic Surveys, 30(2), 228-277.

Dewanti, L., \& Rokhim, R. (2017). Comparative economic value added on Southeast Asian banking industry. Economic Journal of Emerging Markets, 9(1), 74-83.

Donaldson, T., \& Preston, L. E. (1995). The stakeholder theory of the corporation: Concepts, evidence, and implications. Academy of Management Review, 20(1), 65-91.

Fama, E. F., \& Jensen, M. C. (1983). Separation of ownership and control. The Journal of Law and Economics, 26(2), 301-325.

Ghalib, S. (2018). Good corporate governance rating and bank profitability in Indonesia: Evidence from panel data. International Journal of Business \& Society, 19(3).

Goddard, J., Liu, H., Molyneux, P., \& Wilson, J. O. (2011). The persistence of bank profit. Journal of Banking \& Finance, 35(11), 2881-2890.

Haddad, F. S. (2012). The relationship between economic value added and stock returns: Evidence from Jordanian banks. International Research Journal of Finance and Economics, 89(1), 6-14.

Haniffa, R., \& Hudaib, M. (2006). Corporate governance structure and performance of Malaysian listed companies. Journal of Business Finance \& Accounting, 33(7-8), 1034-1062.

Haryati, S., \& Kristijadi, E. (2014). The effect of GCG implementation and risk profile on financial performance at go-public national commercial banks. Journal of Indonesian Economy and Business, 29(3), 237-250.

Hornuf, L., Klus, M., Lohwasser, T., \& Schwienbacher, A. (2018). How Do Banks Interact with Fintechs? Forms of Alliances and their Impact on Bank Value.

Iramani, R. R., Muazaroh, M., \& Mongid, A. (2018). Positive contribution of the good corporate governance rating to stability and performance: Evidence from Indonesia. Problems and Perspectives in Management, 16(2), 1-11.

Jensen, M., \&Meckling, W. H. (1976). Theory of the firm: Managerial behavior,agency costs and ownership structure.Journal of Financial Economics, 3(4), 305-360.

Laeven, L., \& Levine, R. (2009), Bank governance, regulation and risk taking.Journal of Financial Economics, 93(2), 259-275

Le, T. V., \& Buck, T. (2011). State ownership and listed firm performance: A universally negative governance relationship?.Journal of Management \& Governance, 15(2), 227-248.

Li, G., \& Weidong, F. (2003). A study on the value-creating capability of banking industry in China. Finance \& Trade Economics, 11.

Mandilas, A., Floropoulos, I., Pipiliagkopoulos, M., \& Angelakis, G. (2009). EVA reconsidered for the Greek capital market. European Research Studies, 12(2).

Mollah, S., Hassan, M.K.b, Al Farooque, O., Mobarek, A. (2017) "The governance, risk-taking, and performance of Islamic banks". Journal of Financial Services Research, 51(2), 195-219.

Mongid, A., \& Tahir, I. M. (2011). Impact of corruption on banking profitability in ASEAN countries: An empirical analysis. Banks and Bank Systems, 6(1).

Mongid, A., Tahir, I.M., \& Haron, S. (2012). The relationship between inefficiency, risk and capital: Evidence from commercial banks in ASEAN. International Journal of Economics and Management, $6(1), 58-74$

Mongid, A., \& Muazaroh, M. (2017). On the nexus between risk taking and profitability: Evidences from Indonesia. International Journal of Business \& Society, 18(2).

Munteanu, A., \& Brezeanu, P. (2012). Do romanian banking institutions create shareholder value? Procedia Economics and Finance, 3, 144-151. 
Murharsito, M., Fauziah, F. E., Kristijadi, E., \& Iramani, R. (2017). Provincial corruption and local development bank performance. Economic Journal of Emerging Markets, 9(1), 66-73.

Nur'ainy, R., Nurcahyo, B., Sri Kurniasih, A., \& Sugiharti, B. (2013). Implementation of Good Corporate Governance and Its Impact on Corporate Performance: The Mediation Role of Firm Size (Empirical Study from Indonesia). Global Business \& Management Research, Vol5/2\&3

Okike, E., \& Turton, A. (2009). Corporate Governance Reform within the UK Banking Industry and its Effect on Firm Performance. Corporate Ownership and Control, 456.

Peni, E., \& Vähämaa, S. (2012). Did good corporate governance improve bank performance during the financial crisis? Journal of Financial Services Research, 41(1-2), 19-35.

Putra, A., \& Simanungkalit, R. M. (2014). The impact of implementation good corporate governance to firm value (evidence from Indonesia public banking sector). Review of Integrative Business \& Economic Research, 4(1), 95-102.

Saha, A., Ahmad, N. H., \& Yeok, S. G. (2016). Evaluation of performance of Malaysian banks in risk adjusted return on capital (RAROC) and economic value added (EVA) framework. Asian Academy of Management Journal of Accounting \& Finance, 12(1).

Suhartono. S (2017). Productive efficiency of banks in ASEAN countries. Banks and Bank Systems, 12(2), 91-99

Sutopo, B., Trinugroho, I., \& Damayanti, S. M. (2017). Politically connected banks: Some Indonesian evidence. International Journal of Business \& Society, 18(1).

Stewart, B, (1992). The quest for value. HarperCollins, NY.

Tarchouna. A, B. Jarraya \& Bouri, A. (2017). How to explain non-performing loans by many corporate governance variables simultaneously? A corporate governance index is built to US commercial banks. Research in International Business and Finance, 42, 645-657.

Teker, S., \& Sönmez, M. (2011). Economic value added performances of publicly owned banks: Evidence from Turkey. International Research Journal of Finance and Economics, 75, 132-137.

Utama, C. A., Utama, S., \& Amarullah, F. (2017). Corporate governance and ownership structure: Indonesia evidence. Corporate Governance: The International Journal of Business in Society, 17(2), 165-191.

Utama, C. A., \& Utama, S. (2014). Corporate governance, size and disclosure of related party transactions, and firm value: Indonesia evidence. International Journal of Disclosure and Governance, 11(4), 341-365.

Utama, C. A., Utama, S., \& Amin, A. M. (2016). The influence of corporate governance practices and ownership structure on credit ratings: Evidence from Indonesia. Asian Journal of Business and Accounting, 9(2), 41-72.

Xin'e, Z., Ting, W., \& Yuan, Z. (2012). Economic value added for performance evaluation: A financial engineering. Systems Engineering Procedia, 5, 379-387.

Yeh, T. M. (2017), Governance, risk-taking and default risk during the financial crisis: The evidence of Japanese regional banks, Corporate Governance (Bingley), 17(2), 212-229.

Yun, Y., Yiping, H., \& Jin, X. (2004). EVA and the value creation of banking industry. Value Engineering, 5.

Wijaya, C., \& Atmoko, A. W. (2015). Corporate governance with the institutional theory approach on regional development banks in Indonesia. Bisnis \& Birokrasi, 22(2), 100.

Williams, B. (2014). Bank risk and national governance in Asia. Journal of Banking Finance, 49 , $10-26$.

Zheng, X (2014). The application of economic value added on performance evaluation of listed banks In China. Journal of Academic Research in Economic, 6(1), 103-118. 